\title{
Improving Basic Design courses through Competences of Tuning MEDA*
}

\author{
Rafee Hakky** \\ doi: http://dx.doi.org/10.18543/tjhe-4(1)-2016pp21-42
}

\begin{abstract}
It is well established that Tuning's development of the concept of competences for the improvement of what is referred to as student-centered approach has proven itself beneficial in developing higher education programs. ${ }^{1}$ This paper examines the application of competences suggested by Tuning-MEDA to the benefit of teaching architecture. Two courses were selected from the Architectural Engineering Program at the International University for Science and Technology, Damascus, Syria; namely, Basic Design I and II. Five competences were selected as crucial to be achieved in these two courses: ability to think, perceive and conceive spaces three dimensionally and communicate verbally, in writing, graphically, and/or volumetrically; have critical thinking, analysis and synthesis; knowledge of aesthetics and arts, and understanding their role as key factors in the quality of architectural thinking and design; possess a high level of interpersonal skills; and appreciation of the social and cultural role of architecture. The two courses are evaluated at two levels before being examined in relation to their ability to achieve these competences. They were looked at in connection with Bloom's Taxonomy and found to be able to deliver learning at its upper levels; namely, analysis, synthesis, and evaluation. They were also examined against the typical Learning Retention Pyramid and were found to provide learning opportunities through learning techniques which provide a high level of retention: demonstration, group discussion, and practice by doing. Finally, it was found that the five competences assigned to the courses were very much achievable and indeed through applying them, the two courses were more focused and could achieve their objectives more successfully.
\end{abstract}

* The author bases this work on Tuning Middle East Project. He wishes to extend his appreciation to all organizers and researchers in Tuning for their support and help in making this paper reality.

** Rafee Hakky (rihakky2@gmail.com) is Professor and Chairman in the Architectural Engineering Department, College of Engineering, International University for Science and Technology, Damascus, Syria. He holds a Ph.D. in Environmental Design and Planning.

More details are available at the end of this article.

${ }^{1}$ Robert Wagenaar, "Competences and learning Outcomes: a Panacea for Understanding the (New) Role of Higher Education?" Tuning Journal for Higher Education 1, no. 2 (May 2014): 279-302. 
Keywords: Architectural education; basic design; competences; design courses; design education; architectural design.

\section{Introduction}

Schooling systems in almost all Arab countries, including Syria, are based in general on memorizing more than any other teaching technique. Students have strong ability to retain given information in their minds until they enter exams. Afterwards, most information is lost. This lack of ability to maintain information is a result of a teaching culture that emphasizes memorization for the sake of pouring information on exam papers only to get grades. Information or knowledge then is lost because it does not have any purpose beyond this simple objective; in most cases also, it does not have any relevance to life experiences.

Although this problem is strongly crystallized in the Arab world, it has its resonance in almost all schooling systems to different degrees. Students are given "facts" in school. Therefore, one major objective of Basic Design courses in design schools, including architecture, is to open the minds of new students in these fields to the idea that there is no one "fact" in connection to anything, at least in design. Thus, these courses attempt to help students go beyond the basic level of cognition (knowledge and comprehension), according to Bloom's Taxonomy, to the upper levels (starting from application to evaluation). In other words, these courses aim to encourage and guide students to think on their own building on knowledge gained in the classroom.

\section{The Problem}

The International University for Science and Technology in Damascus, Syria is a young university; its first class graduated in 2009. During its first few years, the two Basic Design courses in the Architectural Engineering Program at the University were taught according to at least two different approaches. One approach was to ask students to design a cube whose side was around $30 \mathrm{~cm}$ long using different materials (wood, plastic, metal, etc.). Students were exposed to design elements (point, line, surface, and mass) and to a number of design principles (balance, harmony, hierarchy, etc.). Students' proposals submitted at the end of the courses would theoretically reflect their understanding of the taught principles.

The second approach of teaching the course was to treat it as a regular design course where students would be asked to design a small project and produce basic architectural drawing along with a model. The problem with 
both approaches was that they allow very limited opportunity to systematically help students overcome their inherited drawback in relation to their way of accumulating knowledge and how they can benefit from it.

Both approaches were not successful in addressing two very crucial issues in relation to these critical courses. First, they did not provide the needed body of knowledge expected to be acquired through them. Second, they did not aim to help students change their attitude and approach towards learning to get to higher ranks in the classic Bloom's Taxonomy beyond "application" in the best of cases.

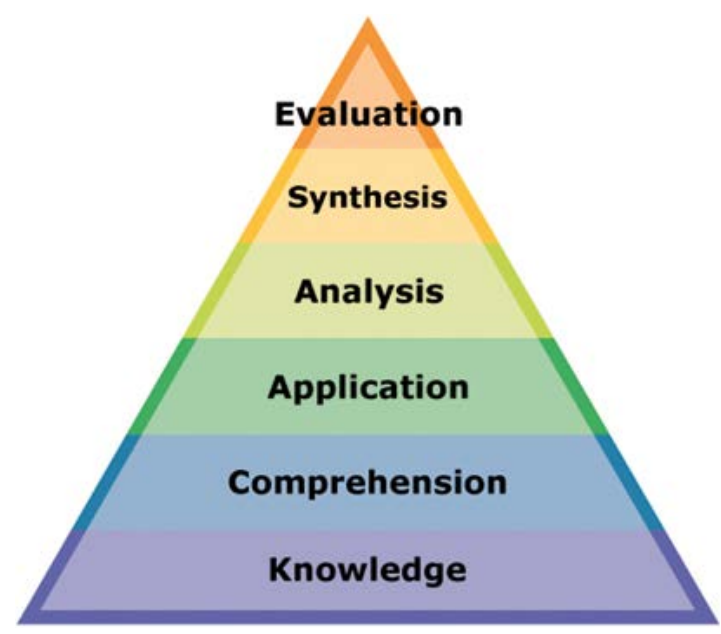

Figure 1

Original version of Bloom's Taxonomy Pyramid

Retrieved 16/4/2016 from: http://www.learnnc.org/lp/pages/4719.

\section{The Proposed Approach ${ }^{2}$}

Any proposed approach to teaching these Basic Design courses was expected to address the drawbacks of earlier approaches. Taking this issue as

2 The development of these two courses is part of a continuous effort to raise the standards of the Program at IUST in order to make it more capable to confirm with Tuning-MEDA. This effort is a reflection of strong belief that development of any program should be a continuous 
a point of departure, this proposed approach was expected to address the type and quantity of information to be introduced in the course; on the other hand, it was to take a stand on how to help students build their own healthy attitude towards architecture and themselves, and to learn how to reflect their conceptual ideas in physical form. Hence, the approach which the author adopted is based on a number of clear objectives:

a) To teach students design principles and spatial organization methods

b) To give students a chance to practice with these principles and methods to master their use

c) To create learning opportunities for students to go beyond the basic levels of Bloom's Taxonomy to the higher levels

d) To help students build a strong and confident yet sensitive personality ${ }^{3}$

e) To help students improve their presentation techniques at all levels

The two Basic Design courses, One and Two, are dealt with as a one year continuous course starting with the very basics of design elements, through design principles, spatial organization, form relationships, spatial definition and enclosure, ending with approach and paths. The program of the two courses is based on the famous book: Architecture: Form, Space, and Order by Francis Ching in its second edition (1996). The book is still considered one of the best works to be used as an introductory to the architectural design field from its formal perspective.

In order to provide students with every possible opportunity to learn, the two courses are designed to benefit from the Learning Pyramid (Adapted from NTL Institute for Applied Behavioral Science). According to the Pyramid, each method of teaching allows a certain average learning retention rate: for example, a student would retain $5 \%$ of the information presented to him in a lecture; ${ }^{4}$ while on the other hand, he or she would retain $90 \%$ of information he or she would teach to colleagues.

process by any school and not a periodical action. See for instance: Thomas Baker and Howard Smith Jr., "Integrating Accreditation into Strategic Planning," Community College Journal of Research and practice vol. 60, no. 3 (February 2007): 21-27

3 The idea of developing students' personality to become good citizens has become central in higher education. See for instance: Wagenaar, "Competences and learning Outcomes: a Panacea for Understanding the (New) Role of Higher Education?" Tuning Journal for Higher Education 1, no. 2 (May 2014): 279-302.

${ }^{4}$ In the case of the architectural design studio, there is no one opinion about the use of lectures. Some value having lectures in studio while others see that lectures should be 


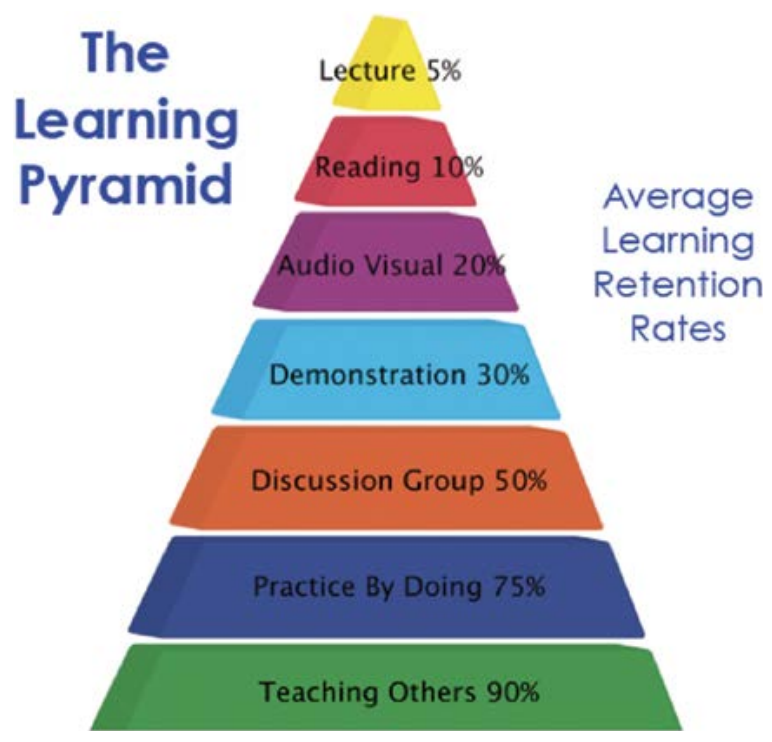

Figure 2

The Learning Pyramid (Adapted from NTL Institute for Applied Behavioral Science)

(Retrieved 16/4/2016 from: http://www.westmuse.org/sites/westmuse.org/files/uploads/2012/ 03/pyramid.png)

The courses use almost all learning techniques to different degrees, table 1 shows, based on the author's estimation, the use of each learning technique in the two courses.

Three very important techniques are heavily used in teaching the courses; namely, demonstration, discussion group, and practice by doing. The use of these three techniques is inevitable in teaching design. Instructors depend greatly on demonstrating to students by action how certain design issues or problems can be solved. Practice by doing is by far the most used technique in teaching design. Students are instructed to tackle different design problems; through their experiences in trying to resolve the issues involved in the design problem they acquire knowledge. In fact, design studios in all design schools are based on this learning technique.

completely abandoned for they do not provide a beneficial ground for true learning of design. See for example: Mark Gelernter, "Reconciling Lectures and Studios," Journal of Architectural Education 41, no. 2 (1988): 46. 
Table 1

Estimated use of learning techniques in the Basic Design courses

\begin{tabular}{|l|r|l|l|l|l|}
\hline \multirow{2}{*}{ The Learning Technique } & \multicolumn{4}{|c|}{ Estimated Use of the Technique } \\
\cline { 3 - 6 } \multicolumn{2}{|l|}{} & Not Used & Slightly Used & Used & Heavily Used \\
\hline Lecture & $5 \%$ & & & & \\
\hline Reading & $10 \%$ & & & & \\
\hline Audio Visual & $20 \%$ & & & & \\
\hline Demonstration & $30 \%$ & & & & \\
\hline Group Discussions & $50 \%$ & & & & \\
\hline Practice by Doing & $75 \%$ & & & & \\
\hline Teaching Others & $90 \%$ & & & & \\
\hline
\end{tabular}

The most beneficial technique according to the Learning Pyramid, which is teaching others, can be seen in the two courses in two ways: first in an indirect way during discussion groups. Usual design studio in the Arab countries is typically based on desk critic where students' projects are critiqued by the instructor individually on the desk of each student. This technique is used all over the world, but it should be supplemented by other techniques. One of those techniques is group discussion which has been seen as very informative. Students learn from each other in many cases more than they learn from formal instructions given by tutors. Discussions among students bring out the best of each one them as they try to prove their points of view. Learning takes place then in a very positive way.

The other way of presenting an opportunity to teach others as a technique of learning is presented through giving students the chance to present a particular issue to the class. Formal presentations require serious preparation and sound understanding of the topic to be presented. Going through such an experience guarantees the retention of information. Another form of teaching others is through the use of students as jurors. Students are divided to small groups, each member of the group presents his or her work and then listens to and discusses with his colleagues his or her work. In such situations, students become very alert and eager to have their logic heard.

It is worth mentioning here that in these two courses, and in fact, in all design courses, it appears that the revised Bloom's Taxonomy is more appropriate. This is because in design, the process of evaluation comes as a 


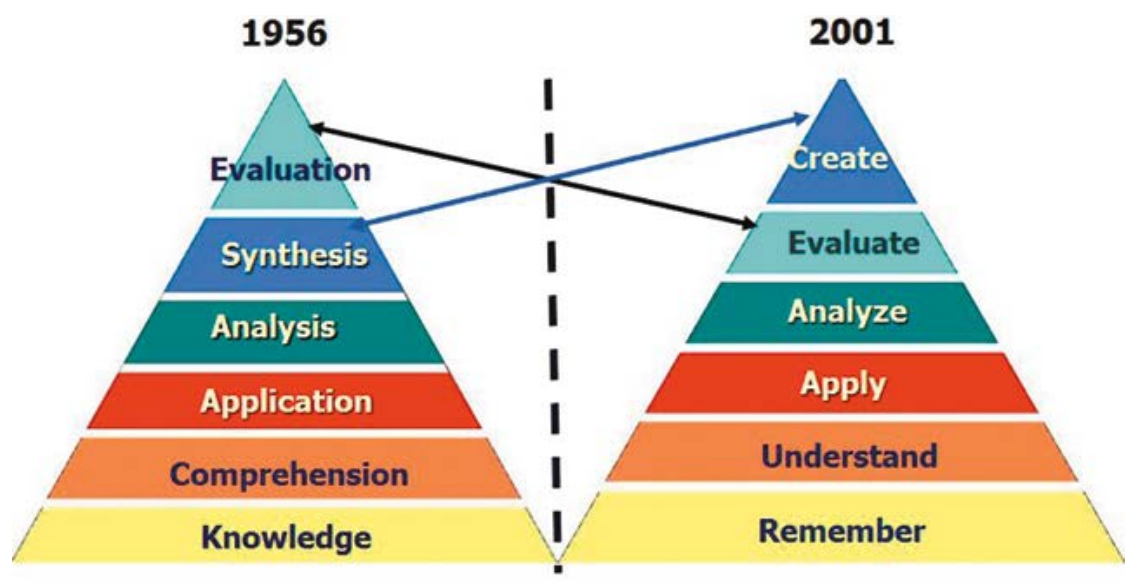

Noun

\section{to Verb Form}

Figure 3

Revised version of Bloom's Taxonomy

Retrieved 10/4/2016 from: http://thesecondprinciple.com/teaching-essentials/beyond-bloomcognitive-taxonomy-revised/

result of the analysis (of the site, users, program, similar projects, etc.). Evaluation leads to the main objective of the whole process which is to design (create in the terms of the revised Bloom's Taxonomy). Thus, in teaching design, students learn to acquire knowledge which they then comprehend. After comprehension they apply this knowledge without full understanding of reasons. In a later and more advanced stage they master the ability to question (analyze) and then take a stand based on the analysis (evaluate). At this stage, students will have the ability to utilize their evaluations as means to improve their work; at this point they become creative.

\section{Tuning-MEDA and the Development of Basic Design Courses ${ }^{5}$}

The new approach used in teaching the two Basic Design courses started in 2011. However, it took a number of adjustments and refinements based on

5 Tuning in its basic objective is not very different from any accreditation system. Its method and process may be different from typical accreditation system, but, like accreditation, its aim is to find a way to evaluate the outcome of an educational program. Thus benefits of any 
accumulated experiences. Tuning-MEDA, which started its work in mid 2013, was an opportunity to evaluate the development of the courses and to examine their validity within a larger scope of the whole curriculum. TuningMEDA proposed a list of competences that each student should acquire during his study period in any architectural program in the concerned region (The Middle East and North Africa) ${ }^{6}$ Based on the list of competences, a proposal for a revised program for the Architectural Engineering Program at the International University for Science and Technology was developed. The proposal attempts to include all the competences which have been agreed upon as necessary, each in the appropriate courses.

Careful assignment of competences to courses is a very crucial endeavor and should be done with good understanding of the capacity of each course and its content on one side, and the comprehensiveness and integration of all courses to form a cohesive and complete program on the other. ${ }^{7}$ Obviously, no course can meet all competences; on the other hand, no course should exist in the program if it does not meet at least one competence. Competences for architectural curriculum were grouped under five main categories: Design abilities, construction and technological abilities, theoretical background and socio-cultural values, professional practice and work ethics, and personal characteristics.

accreditation system are shared by Tuning; these benefits have been stated by many studies in different fields of education, one of which is Wendy Nicklin's work which stated thirty benefits for accreditation in health care specialties. See: Wendy Nicklin, "The Value and Impact of Health Care Accreditation," Accreditation Canada, 2008, 2-4.

${ }^{6}$ Many see Tuning's regional approach needed; as an example, Augusti states: "panEuropean system of accreditation of engineering programmes and qualifications will be essential in order for European engineers to be competitive on a global scale. G Augusti, "Transnational Recognition and Accreditation of Engineering Educational Progammes in Europe: Perspectives in a Global Framework," European Journal of Engineering Education 31, no. 3 (2006): 249-260. On the other hand, others go against Tuning, believing that there is an urgent need to have one 'global model of engineering accreditation that can be used to assess global professional skills and attributes of engineering graduates.' See: Arun Patil and Gary Codner, "Accreditation of Engineering Education: Review, observations and Proposal for Global Accreditation," European Journal of Engineering Education 32, no. 6 (2007): 639-651.

7 A degree profile based on competences is proven to be useful on many levels; one of which is informing students' ahead of time the expected learning outcomes of a particular course. Among the other benefits of the use of competence based programs is quality control of offered education. See Julia Gonzalez and Maria Yarosh, "Building Degree Profiles. The Tuning Approach," Tuning Journal for Higher Education 1, no. 1 (Nov. 2013): 37-69. However, the debate on how to measure a competence is old and can be found in all fields of knowledge, see for instance: Elizabeth Girot, "Assessment of Competence in Clinical Practice - A Review of the Literature," Nurse Education Today 13, no. 2 (April 1993): 83-90. The article questions the meaning of competence and how it can be assessed. 
Among the many changes included in the proposal, the Basic Design courses (which became one, in the proposed program, with higher number of credits: 5 credit course in lieu of the two- 3 credit courses) are supposed to cover the following competences:

1. Ability to think, perceive and conceive spaces three dimensionally and communicate verbally, in writing, graphically, and/or volumetrically (Design abilities 2)

2. Have critical thinking, analysis and synthesis (Theoretical background and socio-cultural values, 5)

3. Knowledge of aesthetics and arts, and understanding their role as key factors in the quality of architectural thinking and design (Theoretical background and socio-cultural values, 7)

4. Possess a high level of interpersonal skills (Personal characteristics, 4$)^{8}$

5. Appreciation of the social and cultural role of architecture (Theoretical background and socio-cultural values, 1$)^{9}$

It is worth noting that all of these competences are considered important generic competences internationally except the third one because it is very specific to architecture..$^{10}$ The fifth competence is included in these two early courses of the Program to emphasize the role of higher education in preparing students to face realities of life and be able to meet society's expectations. ${ }^{11}$ More specifically, students should be aware of economic and cultural issues related to the society for which they are designing.

${ }^{8}$ Interpersonal skills have become essential in all fields including engineering and architecture, see for example Chenicheri Sid Nair, Arun Patil, and Patricie Metrova, "Reengineering Graduate Skills - A Case Study," European Journal of Engineering Education 34, no. 2 (2009): 131-139. Also see: Sanjoy Mazumdar, "Cultural Values in Architectural Education: An Example from India," Journal of Architectural Education 46, no. 4 (1993): 230-238.

${ }^{9}$ Some feel that as early as the first studios in architectural programs, efforts should be made not only to inject an awareness of the importance of multi disciplinary work between architecture and other related fields, but also to give such work a space in these early studios. See: Linda Grroat and Sherry Ahrentzen, "Voices for Change in Architectural Education: Seven Facets of Transformation from the Perspectives of Faculty Women," Journal of Architectural Education 50, no. 4 (1997): 271-285.

${ }^{10}$ Pablo Benitone and Edurne Bartolome, "Global Generic Competences with Local Ownership: a Comparative Study from the Perspective of graduates in Four World Regions," Tuning Journal for Higher Education 1, no. 2, (May 2014): 303-334.

${ }^{11}$ Robert Wagenaar, "Columbus Egg? Qualifications Frameworks, Sectoral Profiles and Degree Programme Profiles in Higher Education," Tuning Journal for Higher Education 1, no. 1 (November 2013): 71-103. 
Accordingly, competences related to such issues should be part of any accreditation or evaluation process. ${ }^{12}$

Three points to be considered here: first, the degree of compatibility between the competences and the original courses' descriptions; second, the relation between the competences and Bloom's Taxonomy; and third, the extent these competences were actually met when teaching the two courses.

\title{
V. Courses' Description, Bloom's Taxonomy, and the Competences
}

Description of courses goes as follows:

\begin{abstract}
305111 Basic Design (1) (3 Credit Hours; Prerequisite: -)
This first semester studio introduces students to design and the formal attributes of compositions. Throughout the use of the basic shapes and forms, the students are expected to identify abstract forms and relate them to practical functions. Upon completion of the course, students are expected to demonstrate an understanding of fundamental principles and primary elements of design.
\end{abstract}

\section{Basic Design (2) (3 Credit Hours; Prerequisite: 305111) \\ This second semester studio introduces students to more contextual and formal complexity in space design. Its main goal is to develop the design mentality among students. The course offers problems that deal with space, measure, structure, sites, etc. Upon completion of the course, the students are expected to demonstrate the ability to transform "design thinking" into an initiation of architectural design and to communicate their ideas in a clear manner.}

The following points can be extracted from the course descriptions as the main issues of the two courses: formal composition, form and function, fundamental principles and primary elements of design, context, design mentality, structure, site, design thinking, communicate ideas. The following table exhibits a matching between these issues and the five competences adopted from Tuning-MEDA.

It appears that issues in the course descriptions are well covered in three competences one way or another. The fourth competence, possess a high level of interpersonal skills, is a general one that should be gained throughout the whole period of education. However, it is highly emphasized in these two courses since they are considered as initiation courses to the field of architecture

${ }^{12}$ See for instance: Marcos Cerqueira, "A literature Review on the Benefits, Challenges and Trends in Accreditation as a Quality Assurance System," 7. 
Table 2

Issues in Basic Design courses covered by Tuning-MEDA competences

\begin{tabular}{|l|l|}
\hline \multicolumn{1}{|c|}{ Competence } & \multicolumn{1}{c|}{ Issues in the course description } \\
\hline $\begin{array}{l}\text { Ability to think, perceive and conceive } \\
\text { spaces three dimensionally and } \\
\text { communicate verbally, in writing, } \\
\text { graphically, and/or volumetrically. }\end{array}$ & $\begin{array}{l}\text { Fundamental principles and primary } \\
\text { elements of design, context, } \\
\text { structure, site, communicate ideas. }\end{array}$ \\
\hline $\begin{array}{l}\text { Have critical thinking, analysis and } \\
\text { synthesis. }\end{array}$ & Design mentality, design thinking. \\
\hline $\begin{array}{l}\text { Knowledge of aesthetics and arts, } \\
\text { and understanding their role as key } \\
\text { factors in the quality of architectural } \\
\text { thinking and design. }\end{array}$ & $\begin{array}{l}\text { Formal composition, form and } \\
\text { function. }\end{array}$ \\
\hline $\begin{array}{l}\text { Possess a high level of interpersonal } \\
\text { skills. }\end{array}$ & \\
\hline $\begin{array}{l}\text { Appreciation of the social and } \\
\text { cultural role of architecture. }\end{array}$ & \\
\hline
\end{tabular}

and the mentality of design. This competence is coupled with the second one, having critical thinking, analysis, and synthesis, in order to build the mentality of a designer who is always questioning, analyzing and then creating. Thus, these two competences, the second and fourth, are concerned with the development of the personality of the young designer in terms of his or her intellectuality and behavior. The first and third competences deal with the technical abilities of the designer; this is to say, his or her ability to compose spaces which correspond to the function and setting of the project. Similarly, the fifth competence, appreciation of the social and cultural role of architecture, is crucial to the development of young architects in order to become more aware and responding to their socio-cultural environment, especially with all the complexity of modern day life. Thus, this competence was added with the idea that it will be included in the revised course description.

Moreover, it is of value to note that Bloom's Taxonomy which appears in its original form to be input based logic, has taken a shape that is more output oriented in its revised form. This is evident in the way it states the details of each level. As an example, the revised Taxonomy explains "Remembering" as: "can the student create a new product or point of view?" These statements present output regardless of the input. They aim at what students can do, as opposed to what was offered to them. 


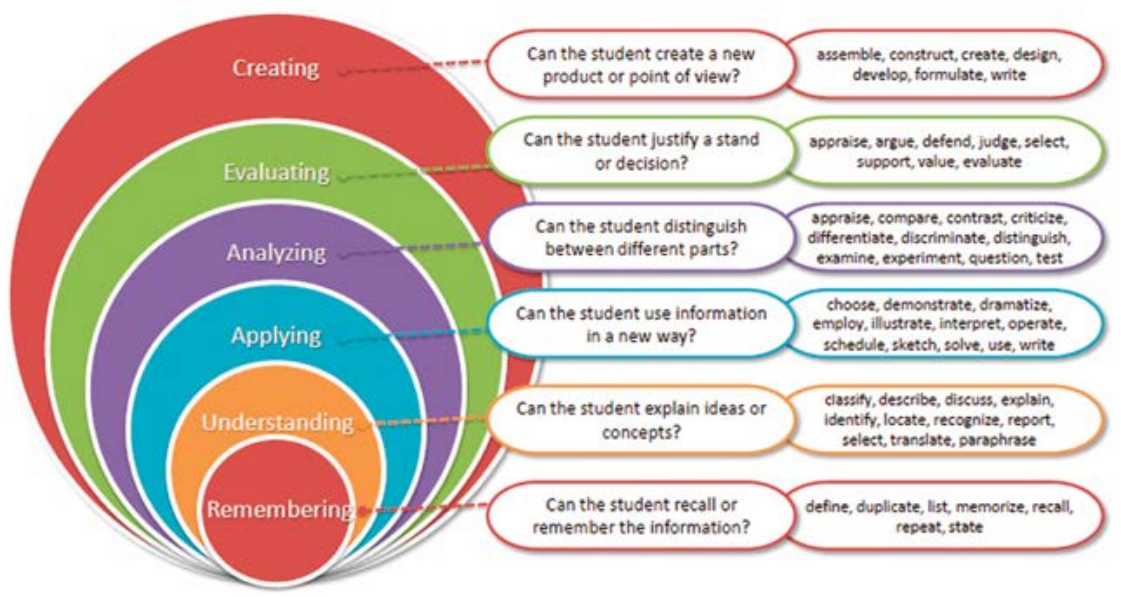

Figure 4

Revised version of Bloom's Taxonomy with detailed explanation of each level

Retrieved 20/8/2016 from http://pcs2ndgrade.pbworks.com/f/1318607148/RBT.PNG

Accordingly, it is possible to see clear matching between Bloom's Taxonomy and the competences aimed by the two Basic Design courses as shown in Table 3. The fourth competence in particular cannot be related directly to any of the six levels of Bloom's Taxonomy since it does not relate to a particular educational task; it is a general competence that talks about the personality of the designer and his or her character. As mentioned earlier, this competence is gained with time and throughout the whole university education of the student.

Table 3

Compatibility between the Competences and Bloom's revised Taxonomy

\begin{tabular}{|l|l|}
\hline \multicolumn{1}{|c|}{ Competence } & \multicolumn{1}{|c|}{$\begin{array}{c}\text { Compatible level(s) of } \\
\text { Bloom's Revised Taxonomy }\end{array}$} \\
\hline $\begin{array}{l}\text { Ability to think, perceive and conceive spaces three } \\
\text { dimensionally and communicate verbally, in writing, } \\
\text { graphically, and/or volumetrically }\end{array}$ & $\begin{array}{l}\text { Understanding } \\
\text { Applying }\end{array}$ \\
\hline Have critical thinking, analysis and synthesis & $\begin{array}{l}\text { Evaluating } \\
\text { Creating }\end{array}$ \\
\hline
\end{tabular}




\begin{tabular}{|l|l|}
\hline \multicolumn{1}{|c|}{ Competence } & $\begin{array}{l}\text { Compatible level(s) of } \\
\text { Bloom's Revised Taxonomy }\end{array}$ \\
\hline $\begin{array}{l}\text { Knowledge of aesthetics and arts, and } \\
\text { understanding their role as key factors in the quality } \\
\text { of architectural thinking and design }\end{array}$ & $\begin{array}{l}\text { Remembering } \\
\text { Understanding }\end{array}$ \\
\hline Possess a high level of interpersonal skills & $\begin{array}{l}\text { Understanding } \\
\text { Evaluation }\end{array}$ \\
\hline $\begin{array}{l}\text { Appreciation of the social and cultural role of } \\
\text { architecture }\end{array}$ & \multicolumn{2}{|l}{} \\
\hline
\end{tabular}

\section{Competences' achievement: Students' appraisal of Basic Design courses}

It is possible to evaluate the results of teaching the two courses in accordance with the new approach in a number of ways. One of these ways is to evaluate them through comparing projects done by students of earlier years with similar projects done by students who have gone through the new way of teaching the Basic Design courses. Theoretically, projects of the second group should show more comprehension of issues addressed in the two courses and better application of them in later work. Another way of evaluating benefits of the new approach is through personal interviews with students to appraise their maturity in the areas discussed in the two courses.

Although there are many possibilities of evaluation, the implementation of a questionnaire was selected. This is because Tuning emphasizes the role of students in the process of developing competence-based educational programs. Their input is seen to be instrumental in the evaluation of any change or development of curricula. ${ }^{13}$ From this perspective, students who studied the courses during the academic year 2014-2015 were asked through a questionnaire to evaluate a number of points related to the way the courses were taught and the benefits of the courses. Forty five students participated in the questionnaire; the results are shown in Table 4.

${ }^{13}$ Alexander Bedny and Liliya Erushkina and Oleg Kuzendov, "Modernising Education Programmes in ICT Based on the Tuning Methodology," Tuning Journal for Higher Education 1, no. 2 (May 2014): 387-404. Also see: Karole Hahn and Damtew Teferra, "Tuning as Instrument of Systematic Higher Education reform and Quality Enhancement: The African Experience," Tuning Journal for Higher Education 1, no. 1 (November 2013): 127-163. 
Table 4

Areas Basic Design courses were helpful to student's learning

The Basic Design courses

\begin{tabular}{|c|c|c|c|c|c|}
\hline & \multirow{3}{*}{$\begin{array}{c}\begin{array}{c}\text { Did not } \\
\text { help me } \\
\text { at all }\end{array} \\
3\end{array}$} & \multirow{3}{*}{$\begin{array}{c}\begin{array}{c}\text { Helped } \\
\text { me a } \\
\text { little }\end{array} \\
\\
8\end{array}$} & \multirow{3}{*}{$\begin{array}{c}\text { Helped } \\
\text { me well }\end{array}$} & \multirow{3}{*}{$\begin{array}{c}\begin{array}{c}\text { Helped } \\
\text { me a } \\
\text { lot }\end{array} \\
17\end{array}$} \\
\hline & & & & & \\
\hline 1 & $\begin{array}{l}\text { Helped my understand the role of } \\
\text { the architect in building healthy } \\
\text { environment }\end{array}$ & & & & \\
\hline 2 & $\begin{array}{l}\text { Helped me be more able to analyze } \\
\text { information }\end{array}$ & 0 & 10 & 19 & 16 \\
\hline 3 & $\begin{array}{l}\text { Helped me be more able to express } \\
\text { my ideas and projects }\end{array}$ & 3 & 10 & 22 & 10 \\
\hline 4 & $\begin{array}{l}\text { Helped me learn about basics of } \\
\text { design }\end{array}$ & 1 & 5 & 15 & 24 \\
\hline 5 & $\begin{array}{l}\text { Helped me learn about different } \\
\text { construction methods }\end{array}$ & 19 & 17 & 7 & 2 \\
\hline 6 & $\begin{array}{l}\text { Helped me better understand } \\
\text { client's needs }\end{array}$ & 8 & 16 & 15 & 6 \\
\hline 7 & $\begin{array}{l}\text { Helped me comprehend the } \\
\text { profession of architecture and its } \\
\text { different dimensions }\end{array}$ & 6 & 10 & 18 & 9 \\
\hline 8 & $\begin{array}{l}\text { Gave me a chance to practically } \\
\text { apply whatever I learned of basics } \\
\text { of design }\end{array}$ & 5 & 15 & 13 & 12 \\
\hline 9 & $\begin{array}{l}\text { Gave me self confidence as a } \\
\text { designer who cares about his/her } \\
\text { surroundings }\end{array}$ & 3 & 11 & 21 & 10 \\
\hline 10 & $\begin{array}{l}\text { Helped me improve my English } \\
\text { language }\end{array}$ & 11 & 20 & 12 & 2 \\
\hline
\end{tabular}

It is helpful to relate the questions of the questionnaire to the competences expected from the two courses. Table 4 shows these relationships; it is to be noted that the last two benefits in the list (helped me learn about different construction methods, and helped me better understand client's needs) are not related to any particular competence. These two benefits were added because they were discussed many times during the courses but were not 
emphasized. Therefore, degree of benefit expected in relation to them should be low. Table 3 confirms this assumption; the lowest level of benefit is in relation to these two points. The third point which earned low rating in terms of its benefit was "improving English language." This evaluation is also very fair because the course did not work on this point but briefly. All principles and important terms were given in English in addition to Arabic. This was the extent to which the course dealt with the issue of second language, no more.

\section{Table 5}

Competences provided by Basic Design courses and corresponding benefits as per the questionnaire

\begin{tabular}{|l|l|}
\hline \multicolumn{1}{|c|}{ Competences } & $\begin{array}{l}\text { Corresponding Benefits from Basic Design } \\
\text { courses as per the questionnaire }\end{array}$ \\
\hline $\begin{array}{l}\text { Ability to think, perceive and conceive } \\
\text { spaces three dimensionally and } \\
\text { communicate verbally, in writing, } \\
\text { graphically, and/or volumetrically. }\end{array}$ & $\begin{array}{l}\text { - Helped me be more able to express } \\
\text { my ideas and projects. } \\
\text { Gave me a chance to practically } \\
\text { apply whatever I learned of basics } \\
\text { of design. }\end{array}$ \\
\hline $\begin{array}{l}\text { Have critical thinking, analysis and } \\
\text { synthesis. }\end{array}$ & $\begin{array}{l}\text { - Helped me be more able to analyze } \\
\text { information. }\end{array}$ \\
\hline $\begin{array}{l}\text { Knowledge of aesthetics and arts, } \\
\text { and understanding their role as key } \\
\text { factors in the quality of architectural } \\
\text { thinking and design. }\end{array}$ & $\begin{array}{l}\text { - Helped me learn about basics of } \\
\text { design. }\end{array}$ \\
\hline $\begin{array}{l}\text { Possess a high level of interpersonal } \\
\text { skills. }\end{array}$ & $\begin{array}{l}\text { - Gave me self confidence as a } \\
\text { designer who cares about his/her } \\
\text { surroundings. } \\
\bullet \text { Helped me improve my English } \\
\text { language. }\end{array}$ \\
\hline $\begin{array}{l}\text { Appreciation of the social and } \\
\text { cultural role of Architecture. }\end{array}$ & $\begin{array}{l}\text { - Helped my understand the role of } \\
\text { the architect in building healthy } \\
\text { environment. } \\
\text { Helped me comprehend the } \\
\text { profession of architecture and its } \\
\text { different dimensions. }\end{array}$ \\
\hline $\begin{array}{l}\text { Helped me learn about different } \\
\text { construction methods. }\end{array}$ \\
$\begin{array}{l}\text { - Helped me better understand } \\
\text { client's needs. }\end{array}$ \\
\hline
\end{tabular}


However, looking at the rest of the points which are more directly related to the competences, it is clear that students feel they have benefited greatly. For instance, the second point (helped me be more able to analyze information), the third point (helped me be more able to express my ideas and projects), the fourth point (helped me learn about basics of design), the eighth point (gave me a chance to practically apply whatever I learned of basics of design), and the ninth point (gave me self confidence as a designer who cares about his/her surroundings) have all very high rating. These results are clearly indicative of the success of the two courses in achieving their intended objectives. Formulating the objectives in clear competences was undoubtedly instrumental in this success.

The other aspect of the search for ways to better benefit students in achieving attempted competences is investigating the appropriate teaching technique. Table 5 concentrates on three competences out of five planned for these courses; namely, ability to think, perceive and conceive spaces three dimensionally and communicate verbally, in writing, graphically, and/or volumetrically; have critical thinking, analysis and synthesis; and possess a high level of interpersonal skills. The first competence is covered in question 1,2 , and 3 . The second competence is covered in question 4 , while the third is covered in the remaining questions. These remaining questions are directly taken from the sub-competences which were originally discussed in earlier stages of developing the final list of competences and were then grouped under it. ${ }^{14}$

\section{Table 6}

Three Competences and corresponding questions from the questionnaire

\begin{tabular}{|c|c|c|}
\hline & Competence & Corresponding Questions \\
\hline 1 & $\begin{array}{l}\text { Ability to think, perceive and } \\
\text { conceive spaces three dimensionally } \\
\text { and communicate verbally, in } \\
\text { writing, graphically, and/or } \\
\text { volumetrically }\end{array}$ & $\begin{array}{l}\text { 2. My ability to perceive and } \\
\text { imagine spaces } \\
\text { 3. My ability to express my design } \\
\text { ideas orally and graphically }\end{array}$ \\
\hline 2 & $\begin{array}{l}\text { Have critical thinking, analysis and } \\
\text { synthesis }\end{array}$ & $\begin{array}{l}\text { 4. My ability to think, analyze, and } \\
\text { synthesize }\end{array}$ \\
\hline 3 & $\begin{array}{l}\text { Possess a high level of interpersonal } \\
\text { skills }\end{array}$ & The rest of the questions \\
\hline
\end{tabular}

14 Tuning for the Middle East and North Africa: Architecture, Fourth Report, University of Deusto, 16, 3, 2016. 
These three competences are more tuned with the intention of the courses. The other two competences (knowledge of aesthetics and arts and understanding their role as key factors in the quality of architectural thinking and design, and appreciation of the social and cultural role of Architecture) are introduced in the two studied courses, but are better addressed in later and more advanced courses in the curriculum.

Table 7 exhibits clear distinction of four teaching techniques: lecturing, demonstration, group discussion, and practice by doing. Lecturing in particular shows the highest points; this is expected since materials of the two courses are first presented in lecture form and then addressed in more detail through exercises. These exercises are done individually in general; which make them fit the practice by doing teaching technique. During students work on their exercises and while evaluating their work, the other two teaching techniques, demonstration and group discussions, come to the fore. The courses, like all design courses, depend heavily on the instructor demonstrating to students how certain things are solved or done, and on rigorous group discussions. Students' answers reflect the importance of these techniques.

\section{Table 7}

Effect of teaching techniques on students learning and personal growth (students can choose more than one option)

The most helpful teaching techniques for my development were in connection to:

\begin{tabular}{|c|c|c|c|c|c|c|c|c|c|}
\hline & & 岕 & 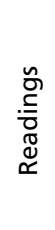 & 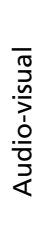 & 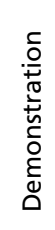 & 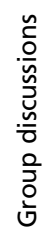 & 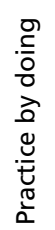 & 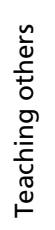 & 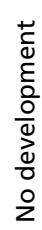 \\
\hline 1 & My personality as an architect & 20 & 3 & 2 & 12 & 29 & 10 & 6 & 0 \\
\hline 2 & $\begin{array}{l}\text { My ability to perceive and } \\
\text { imagine spaces }\end{array}$ & 26 & 2 & 5 & 18 & 8 & 21 & 3 & 0 \\
\hline 3 & $\begin{array}{l}\text { My ability to express my design } \\
\text { ideas orally and graphically }\end{array}$ & 13 & 4 & 1 & 17 & 12 & 17 & 4 & 5 \\
\hline 4 & $\begin{array}{l}\text { My ability to think, analyze, and } \\
\text { synthesize }\end{array}$ & 15 & 4 & 3 & 12 & 15 & 19 & 1 & 1 \\
\hline 5 & $\begin{array}{l}\text { My ability to adapt to different } \\
\text { situations }\end{array}$ & 8 & 3 & 0 & 5 & 11 & 18 & 1 & 5 \\
\hline
\end{tabular}




\begin{tabular}{|c|c|c|c|c|c|c|c|c|c|}
\hline & & 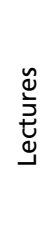 & 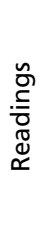 & $\begin{array}{l}\frac{\pi}{7} \\
\frac{n}{2} \\
\frac{0}{1} \\
\frac{0}{0} \\
\frac{1}{4}\end{array}$ & 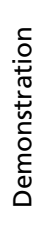 & 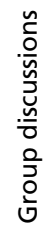 & 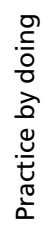 & 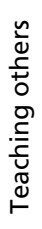 & 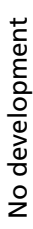 \\
\hline 6 & My ability to work autonomously & 6 & 7 & 4 & 4 & 6 & 23 & 3 & 1 \\
\hline 7 & My ability to take initiatives & 5 & 1 & 0 & 11 & 12 & 9 & 9 & 4 \\
\hline 8 & $\begin{array}{l}\text { My feeling of commitment to } \\
\text { work }\end{array}$ & 19 & 2 & 0 & 6 & 9 & 17 & 0 & 1 \\
\hline 9 & My feeling of dedication & 25 & 2 & 0 & 7 & 15 & 7 & 2 & 1 \\
\hline 10 & My ability to be assertive & 12 & 4 & 1 & 8 & 12 & 11 & 2 & 8 \\
\hline
\end{tabular}

These results are exactly compatible with the estimated use of learning techniques presented in Table 1 . The results are in general very promising when looked at from the Learning Pyramid perspective. This is because three learning techniques with the highest rate of retention are used: demonstration $(30 \%)$, group discussion $(50 \%)$, and practice by doing (75\%). It is worth mentioning that in an informal discussion with the new group of students who are taking the two courses in this academic year (2015-2016), they indicated that the most beneficial time for them is when they get involved in group discussions. Teaching others is a technique that is not well introduced yet, but some experimentation with it is in order. One last remark here is related to point 8 and 9 (my feeling of commitment to work and my feeling of dedication), these two issues were discussed in length throughout the two courses during lectures just to build in students a stronger feeling of responsibility; it seems that it worked.

The questionnaire gave positive responses in general. However, there are a number of issues one cannot ignore. Firstly, the number of students who participated in the questionnaire although not small, but it represents only one batch of students. It would definitely be more reflective if more than one batch participated. Thus, repeating the questionnaire for two more years perhaps may bring about new results and/or support existing ones.

Another worthy point to be mentioned is that students who participated in the questionnaire were freshmen; they were not aware of other methods of teaching and thus they had no reference points for comparison. In this regard, a supporting questionnaire targeting faculty who can compare the new 
approach with old ones may be very useful. Nevertheless, informal discussions with teaching assistants who assisted in both new and old ways of approaching these two courses expressed favorable views of the new method.

A third point related to the questionnaire has to do with the major change in teaching approach between high school and the university. Students usually come from a very restrictive and limited teaching system at school to suddenly a much more open and versatile system. Students feel freedom, maturity, responsibility, and excitement at the time they take these two courses at the beginning of their university education. All this change may have given the courses some advantage; and thus, students' evaluation may not be as objective as one would have liked it to be.

Finally, the two courses are practical ones where students "play" with forms and shapes; they get exposed to completely new techniques of interaction with information. They do not just absorb information; they directly employ it in their work. This by itself is very exciting at times, although it can be frustrating too. It is to be noted that all these points do not take away from the value of the questionnaire. Students responded with maturity as it was explained in the discussion of the results. These warning remarks are only to open the door for more detailed evaluation to support the results which were very positive in the initial examination.

\section{Summary and Conclusions}

This paper documented an experimentation related to applying the competence approach to developing curricula as introduced by TuningMEDA based on student-centered approach..$^{15}$ The experimentation focused on two basic design courses offered in the first year of the Architectural Engineering Program at the International University for Science and Technology, Damascus, Syria. The two courses were redeveloped to concentrate on three main competences defined by Tuning-MEDA architectural group. These were: ability to think, perceive and conceive spaces three dimensionally and communicate verbally, in writing, graphically, and/or volumetrically; have critical thinking, analysis and synthesis; and

15 This sort of activity has become standard in higher education for the improvement of education systems which has become increasingly interested in seeing students as the center of the whole process of education. See for instance: Anna Serbati and Alessio Surian, "Developing Reflection on Competence-Based Learning: the Russian Experience with the Tuning Approach,” Tuning Journal for Higher Education 1, no. 2 (May 2014): 463-481. 
possess a high level of interpersonal skills. Two more competences were also analyzed but to a lesser degree: knowledge of aesthetics and arts, and understanding their role as key factors in the quality of architectural thinking and design; and appreciation of the social and cultural role of architecture.

The study was basically based on a questionnaire along with the instructor's own evaluation of the way the two courses were taught. Results indicated very clearly that all five competences were well recognized by students and that they feel very strongly about their competence to deal with the topics introduced to them during the course. They also feel very strongly that the most effective tools of teaching were: lecturing, demonstration, group discussions, and practice by doing.

It can be concluded that the two courses helped students get beyond the first three levels in Bloom's Taxonomy of learning to reach the upper three levels to different degrees. They were trained to analyze, synthesize, and evaluate. Moreover, students' learning was achieved through learning techniques that guarantee high level of retention. They benefited from chances to learn through demonstration, group discussions, and practice by doing. Most importantly, the five competences adopted from Tuning-MEDA and were aimed for the two courses were achieved to a very acceptable extent.

The experimentation showed that it is possible to modify courses in the curriculum at a detailed level without the application of major changes in their core objective so as to match critical competences advanced by TuningMEDA. It can also be concluded that if Tuning-MEDA is used in conjunction with Bloom's Taxonomy and the Learning Pyramid, the three together can enhance the quality of learning in a very noticeable way.

\section{Bibliography}

Augusti, Giuliano. "Transnational Recognition and Accreditation of Engineering Educational Programmes in Europe: Perspectives in a Global Framework." European Journal of Engineering Education 31, no. 3 (2006): 249-260.

Baker, Thomas, and Howard Smith Jr. "Integrating Accreditation into Strategic

Planning." Community College Journal of Research and Practice 60, no. 3 (February 2007): 21-27.

Bedny, Alexander, Liliya Erushkina, and Oleg Kuzendov. "Modernising Education

Programmes in ICT Based on the Tuning Methodology." Tuning Journal for

Higher Education 1, no. 2 (May 2014): 387-404.

Beneitone, Pablo, and Edurne Bartolomé. "Global Generic Competences with Local

Ownership: a Comparative Study from the Perspective of graduates in Four 
World Regions." Tuning Journal for Higher Education 1, no. 2 (May 2014): 303-334.

Cerqueira, Marcos., A Literature Review on the Benefits, Challenges and Trends in Accreditation as a Quality Assurance System, p. 7.

Gelernter, Mark. "Reconciling Lectures and Studios." Journal of Architectural Education 41, no. 2 (1988): 46.

Girot, Elizabeth. "Assessment of Competence in Clinical Practice - A Review of the Literature." Nurse Education Today 13, no. 2 (April 1993): 83-90.

Gonzalez, Julia, and Maria Yarosh, "Building Degree Profiles. The Tuning Approach," Tuning Journal for Higher Education 1, no. 1, (Nov. 2013): 37-69.

Groat, Linda, and Sherry B. Ahrentzen. "Voices for Change in Architectural Education: Seven Facets of Transformation from the Perspectives of Faculty Women," Journal of Architectural Education 50, no. 4 (1997): 271-285.

Hahn, Karola, and Damtew Teferra. "Tuning as Instrument of Systematic Higher Education reform and Quality Enhancement: The African Experience." Tuning Journal for Higher Education 1, no. 1 (November 2013): 127-163.

http://thesecondprinciple.com/teaching-essentials/beyond-bloom-cognitivetaxonomy-revised/ (Retrieved 10/4/2016).

http://www.westmuse.org/sites/westmuse.org/files/uploads/2012/03/pyramid.png (Retrieved 16/4/2016).

Mazumdar, Sanjoy. "Cultural Values in Architectural Education: An Example from India.” Journal of Architectural Education 46, no. 4, (1993): 230-238.

Nicklin, Wendy, The Value and Impact of Health Care Accreditation. Accreditation Canada, 2008, pp. 2-4.

Patil, Arun, and Gary Codner. "Accreditation of Engineering Education: Review, Observations and Proposal for Global Accreditation." European Journal of Engineering Education 32, no. 6 (2007): 639-651.

Serbati, Anna, and Alessio Surian. "Developing Reflection on Competence-Based Learning: the Russian Experience with the Tuning Approach." Tuning Journal for Higher Education 1, no. 2 (May 2014): 463-481.

Sid Nair, Chenicheri, Arun Patil, Patricie Metrova. "Re-engineering graduate skills - a case study." European Journal of Engineering Education 34, no. 2 (2009): 131-139.

Tuning for the Middle East and North Africa: Architecture. Fourth Report, University of Deusto, 16, 3, 2016.

Wagenaar, Robert. "Columbus Egg? Qualifications Frameworks, Sectoral Profiles and Degree Programme Profiles in Higher Education," Tuning Journal for Higher Education 1, no. 1 (November 2013): 71-103.

- "Competences and learning Outcomes: a Panacea for Understanding the (New) Role of Higher Education?" Tuning Journal for Higher Education 1, no. 2 (May 2014): 279-302. 


\section{About the Author}

RAFEE HAKKY (rihakky2@gmail.com), Professor and Chairman, Architectural Engineering Department, College of Engineering, International University for Science and Technology, Damascus, Syria. He has a Bachelor Degree in Architectural Engineering, Master's of Landscape Architecture, and Ph.D. in Environmental Design and Planning. He taught in Virginia Polytechnic Institute and State University, Blacksburg, Virginia between 1986 to 1992; Dammam University (previously King Faisal University), Dammam, Saudi Arabia between 1992 and 2004, and Bahrain University, Bahrain, between 2004 and 2010, before joining IUST. His main research areas are architectural education, housing design, and history and theory of architecture. He has done a number of studies related to housing in Saudi Arabia and Syria, and architectural education in the Gulf Region and the Middle East. He participated in the preparation of accreditation files for both the architectural and interior design programs at Bahrain University and is currently redeveloping the architectural program at IUST based on finding of Tuning Middle East. 


\section{Improving Basic Design courses through Competences of Tuning MEDA*}

Rafee Hakky

\section{Copyright}

Copyright for this article is retained by the Publisher. It is an Open Access material that is free for download, distribution, and or reuse in any medium only for non-commercial purposes; provided any applicable legislation is respected, the original work is properly cited, and any changes to the original are clearly indicated. 